\title{
ZOSTAVENIE SÚBORU KLÚČOVÝCH INDIKÁTOROV FINANČNEJ VÝKONNOSTI PODNIKU
}

\author{
Zuzana Závarská
}

\section{Kl’účové slová:}

finančná výkonnost', tradičné finančné ukazovatele, moderné finančné ukazovatele, korelačná analýza

\section{Key words:}

Financial Performance, Traditional Financial Indexes, Modern Financial Indexes, Correlation analysis

\begin{abstract}
Abstrakt:
Jedným z relevantných dôsledkov globalizačných procesov je zostrenie konkurenčného prostredia a následný tlak na výkonnost' podnikatel'ských subjektov. V posledných rokoch sa popri tradičných ukazovatel'och finančnej výkonnosti kladie dôraz tiež na moderné ukazovatele založené na teórii riadenia hodnoty podniku. Na mieste je tu preto otázka: „Ktoré ukazovatele možno považovat' za kl'účové pri hodnotení vývoja finančnej výkonnosti podniku?"“.

Paleta finančných ukazovatel'ov indikujúcich finančnú výkonnost' podniku je pomerne rozsiahla. Niektoré ukazovatele sú navzájom úzko prepojené (napr. ukazovatele rentability), no medzi inými nemusí byt' priama súvislost' (napr. celková likvidita a rentabilita vlastného imania). Ukazovatele, ktoré vykazujú silnú koreláciu (t. j. ich hodnoty sa vyvíjajú jedným smerom - v smere zlepšenia alebo v smere zhoršenia), nie je nutné sledovat' a riadit' súbežne. Za týmto účelom postačí sledovat' a riadit' iba jeden ukazovatel', a to ten, ktorý nie je v žiadnej, prípadne je v štatisticky nevýznamnej korelácii s ukazovatel'mi mimo tejto skupiny.

Vyššie načrtnutá úvaha viedla ku formulácii ciel’a predkladaného príspevku: „Na základe výsledkov korelačnej analýzy zostavit' súbor kl’účových indikátorov finančnej výkonnosti podniku, ktorý by hodnoverne odrážal finančnú výkonnost' podniku. Súbor indikátorov má obsahovat' čo najnižší možný počet finančných ukazovatel'ov.“
\end{abstract}

\begin{abstract}
:
One of the significant consequences of the globalization processes is the sharpening of the competitive environment and the sharpening of the subsequent pressure on the business efficiency. Beside the traditional indicators, in the last years the accent is putted on the modern firm performance indicators based on the theory of the shareholder value. The palette of the firm financial performance indicators is therefore relatively broad, what is the reason why the financial analytics stay in front of the problem to choose the set of indicators which would reflect the firm financial performance most precise.
\end{abstract}

Some of the indicators are in the significant correlation (for instance return indexes), but between another non significant or no correlation exists (for instance return on equity and solvency). In the case of the strong significant correlation it is sufficient to manage only one indicator of that category - that one which is in none or in the statistical non significant correlation with the indicators out of that category. 
The main goal of the submitted paper is to compile the set of the key indicators of the firm financial performance what would reflect the financial performance reliable and would rectify the effort of financial analytics to increase it. The starting point to fulfil the goal of this paper is the identification of those financial indicators between none or the statistical insignificant correlation exists.

\section{Úvod}

Začlenením sa Slovenskej republiky do globalizačných štruktúr prechádzali slovenské podniky mnohými výraznými makroekonomickými a mikroekonomickými zmenami ${ }^{1}$. Jednou z pozitívnych zmien je vytváranie nových príležitostí, ktoré môžu využit' predovšetkým výkonné podniky. V priebehu času došlo ale aj ku zmenám vo vnímaní výkonnosti podniku ako uvádza Kislingerová a Nový (2005), dôraz je kladený na pojmy ako dlhodobá vízia, výkonnost' či hodnota podniku. Paleta finančných ukazovatel'ov indikujúcich finančnú výkonnost' podniku sa tak rozšírila o tzv. moderné finančné ukazovatele.

Je zrejmé, že čím viac finančných ukazovatel'ov finančný analytik sleduje, tým exaktnejší obraz o finančnej situácii podniku získa. S rastom počtu sledovaných ukazovatel’ov ale vzniká riziko zahltenia účtovnými informáciami. Je preto účelné, aby finančný analytik sledoval súbor niekol'kých ukazovatel'ov, ktoré by hodnoverne odrážali finančnú výkonnost' podniku. Ciel'om predkladaného príspevku je preto zostavit' súbor indikátorov finančnej výkonnosti, prostredníctvom ktorého by bolo možné pomerne presne identifikovat' vývoj finančnej výkonnosti podniku zohl'adňujúci tiež modernú koncepciu ekonomickej pridanej hodnoty.

\section{Ukazovatele finančnej výkonnosti}

Literatúra uvádza relatívne široký okruh finančných ukazovatel'ov, prostredníctvom ktorých možno identifikovat' finančnú výkonnost' podniku. Medzi najčastejšie ukazovatele, ktoré charakterizujú výkonnost' podniku vo finančnej perspektíve, sa radia nižšie vymenované finančné ukazovatele. Ide o tradičné ukazovatele, ktoré možno členit' na absolútne a relatívne, a tiež o tzv. moderné ukazovatele, ktoré vychádzajú z koncepcie ekonomického zisku.

\section{Absolútne ukazovatele finančnej výkonnosti}

Medzi najčastejšie v podnikatel'skej praxi používané absolútne ukazovatele finančnej výkonnosti sa radí hrubý zisk, čistý zisk, tržby, náklady, pridaná hodnota a čistý cash-flow. Nevýhodou týchto ukazovatel'ov je fakt, že ich nemožno použit' na medzipodnikové porovnávanie. Tento nedostatok sa ale dá eliminovat' tak, že sa tieto hodnoty dajú do pomeru ku nejakej základni, napr. ku výške podnikových pasív.

Spomedzi absolútnych ukazovatel'ov má najvyššiu vypovedaciu schopnost' predovšetkým vývoj tržieb, pridanej hodnoty a cash-flow. Pri zvažovaní ostatných ukazovatel'ov je nutné zohl'adňovat' rôzne interné a externé vplyvy. Napríklad účtovný zisk môže byt' ovplyvnený jednorazovou investíciou, spôsobom odpisovania dlhodobého majetku či novelizáciou daňových zákonov. Rast nákladov môže byt' tiež vyvolaný investíciou, ktorá v dlhodobejšom horizonte prinesie úžitky vo forme výnosov. Rast nákladov môže byt' ale vyvolaný tiež nehospodárnost'ou podnikatel'skej jednotky.

V prípade medzipodnikového porovnávania treba brat' do úvahy príslušnost' podniku $\mathrm{k}$ odvetviu.

\footnotetext{
${ }^{1}$ Tento príspevok je jedným z výstupov v rámci riešenia grantovej úlohy VEGA č. 1/0541/11 Analýza determinantov výkonnosti subjektov hospodáriacich na pôde podl’a regionálnej diferenciácie.
} 


\section{Relatívne ukazovatele finančnej výkonnosti}

Medzi významné relatívne ukazovatele finančnej výkonnosti sa radia ukazovatele rentability, aktivity a likvidity. Z ukazovatel'ov rentability je potrebné zdôraznit' predovšetkým rentabilitu aktív, rentabilitu vlastného imania, rentabilitu investovaného kapitálu a rentabilitu nákladov. Ukazovatele rentability majú značnú vypovedaciu schopnost' o výkonnosti podniku, avšak pri ich vyčísl'ovaní vystupuje v čitateli zlomku výška čistého zisku, čo môže skreslit' výsledok šetrenia.

Ďalšou významnou skupinou sú ukazovatele aktivity, spomedzi ktorých je potrebné zdôraznit' najmä obrat zásob, celkový stav zásob, dobu obratu záväzkov, dobu obratu pohl'adávok či výšku nedobytných pohl'adávok. Vývoj týchto ukazovatel'ov je vhodné porovnávat' s konkurenciou v príslušnom odvetví.

Poslednou významnou skupinou relatívnych ukazovatel'ov finančnej výkonnosti sú ukazovatele likvidity, a to najmä okamžitá likvidita, likvidita prvého stupňa a celková likvidita. Tieto ukazovatele majú vysokú vypovedaciu schopnost' o platobnej schopnosti podniku a v konečnom dôsledku aj o finančnom zdraví podniku.

\section{Moderné ukazovatele finančnej výkonnosti}

Medzi ukazovatele zohl'adňujúce koncepciu riadenia hodnoty sa radia ukazovatele vychádzajúce z ekonomického zisku podniku. Jedná sa predovšetkým o ekonomickú pridanú hodnotu (EVA) a hodnotu pridanú trhom (MVA). Tieto ukazovatele sledujú vývoj tzv. nadzisku, ktorý zostáva $\mathrm{v}$ rukách vlastníka podniku po odpočítaní oportunitných nákladov. Spomínané ukazovatele si podl'a Závarskej (2008) postupne razia cestu ku meraniu finančnej výkonnosti aj v slovenských podnikoch.

\section{Materiál a metodologický postup vedeckej práce}

Riešenie vedeckej úlohy bolo podriadené nasledovnej postupnosti:

1. Stanovenie hlavného ciel’a vedeckej práce - na základe výsledkov korelačnej analýzy zostavit' súbor kl'účových indikátorov finančnej výkonnosti podniku, ktorý by hodnoverne odrážal finančnú výkonnost' podniku.

2. Selekcia ukazovatel'ov finančnej výkonnosti - spomedzi tradičných a moderných ukazovatel'ov budú zvolené tie, ktorých vývoj je najmenej ovplyvnený rôznymi vonkajšími a vnútornými faktormi.

3. Zostavenie výberovej vzorky podnikov - vstupným zdrojom dát bude databáza Ministerstva pôdohospodárstva SR získaná za účelom riešenia projektu VEGA 1/0541/11 Analýza determinantov výkonnosti subjektov hospodáriacich na pôde podl'a regionálnej diferenciácie.

4. Výber korelačných koeficientov a korelačná analýza - rozhodovacím kritériom bude normalita premenných (finančných ukazovatel'ov).

5. Vyhodnotenie výsledkov korelačnej analýzy.

6. Zostavenie súboru kl'účových indikátorov finančnej výkonnosti podniku prostredníctvom vylúčenia ukazovatel’ov, ktoré sú v štatisticky významnej korelácii s inými ukazovatel'mi.

\section{Analyzované finančné ukazovatele a metodika ich selekcie}

Na základe analýzy teoretických poznatkov z oblasti merania finančnej výkonnosti podniku bolo vybraných 14 ukazovatel'ov finančnej výkonnosti:

- produkčná sila (EBIT/A),

- rentabilita aktív (EAT/A a EBET/A),

* rentabilita vlastného imania (ROE), 
- rentabilita tržieb (EBIT/R a EAT/R),

* obrat aktív (R/A),

- podiel pridanej hodnoty na tržbách $(\mathrm{PH} / \mathrm{R})$,

- podiel pridanej hodnoty na aktívach (PH/A),

- podiel ekonomickej pridanej hodnoty na čistých operatívnych aktívach (EVA/NOA),

- ako aj štyri ukazovatele likvidity - celková likvidita, bežná likvidita, pohotová likvidita a platobná neschopnost'.

\begin{tabular}{|l|}
\hline Vysvetlivky: \\
\hline EBIT - Earnings before interest and taxes (hrubý zisk pred platením úrokov) \\
\hline EBET - Earnings before taxes (hrubý zisk) \\
\hline EAT - Earnings after taxes (čistý zisk) \\
\hline A - Assets (aktíva) \\
\hline ROE - Return on Equity (rentabilita vlastného imania, t. j. podiel čistého zisku na vlastnom imaní podniku) \\
\hline R - Revenue (tržby) \\
\hline PH - pridaná hodnota \\
\hline $\begin{array}{l}\text { EVA - Economic Value Added (ekonomická pridaná hodnota, t. j. čistý operatívny zisk po odpočítaní nákladov } \\
\text { na vlastný kapitál) }\end{array}$ \\
\hline NOA - Net Operating Assets (čisté operatívne aktíva, t. j. aktíva súvisiace s hlavnou podnikatel'skou činnostou) \\
\hline
\end{tabular}

Autorka má za to, že ukazovatele rentability významným spôsobom indikujú finančnú výkonnost' podniku. Preto bolo medzi analyzované ukazovatele zaradených 6 ukazovatel'ov rentability (EBIT/A, EAT/A, EBET/A, ROE, EBIT/R a EAT/R).

Spomedzi ukazovatel'ov aktivity bol zvolený jeden ukazovatel', a to obrat aktív (R/A). Dôvodom pre vol'bu tohto ukazovatel'a bol fakt, že typická štruktúra aktív v členení na dlhodobý a obežný majetok, ako aj typická štruktúra obežného majetku, je rôzna v jednotlivých odvetviach národného hospodárstva. Pri sledovaní iných ukazovatel'ov aktivity možno očakávat' značné odlišnosti pri podnikoch pôsobiacich v rôznych odvetviach.

Pridaná hodnota má pre podnik významnú vypovedaciu schopnost'. Vyčísl'uje rozdiel medzi hodnotou finálnej produkcie (výrobkov alebo služieb) a hodnotou výrobných vstupov. Preto boli do šetrenia zaradené tiež dva ukazovatele pridanej hodnoty (PH/R a PH/A).

Spomedzi moderných ukazovatel'ov založených na teórii hodnoty podniku bol vybraný jeden ukazovatel' - podiel ekonomickej pridanej hodnoty na čistých operatívnych aktívach (EVA/NOA).

Ukazovatele likvidity vypovedajú o platobnej schopnosti podniku, a preto značne ovplyvňujú finančnú výkonnost' podniku. Podnik, ktorý je v platobnej neschopnosti, nemôže byt' dlhodobo výkonný. $\mathbf{Z}$ ukazovatel'ov likvidity boli preto zvolené štyri ukazovatele - celková likvidita, bežná likvidita, pohotová likvidita a platobná neschopnost ${ }^{2}$.

\footnotetext{
${ }^{2}$ Celková likvidita sa vypočíta ako podiel obežného majetku a krátkodobých záväzkov. Ak je hodnota ukazovatel'a menšia než jedna, potom je čast' dlhodobého majetku financovaná krátkodobými cudzími zdrojmi.

Bežná likvidita sa vypočíta ako pomer súčtu finančných účtov a krátkodobých pohl'adávok ku krátkodobým záväzkom. Optimálne hodnoty sú v intervale od 1,0 do 1,5.

Pohotová likvidita sa vypočíta sa ako pomer finančných účtov ku krátkodobým záväzkom.

Platobná neschopnost' sa vypočíta ako pomer záväzkov a pohl'adávok. Ak je ukazovatel' vyšší než 1, podnik vo väčšej miere využíva dodávatel'ský úver. Môže to ale predpovedat' tiež prvotnú platovú neschopnost'. Ak je ukazovatel' menší než 1, indikuje to dobrú platobnú disciplínu, ale môže to znamenat' tiež druhotnú platobnú neschopnost'.
} 
Z absolútnych ukazovatel'ov finančnej výkonnosti nebol zvolený žiaden, nakol'ko hodnoty týchto ukazovatel'ov nie je možné medzipodnikovo porovnávat'.

Na výpočet jednotlivých ukazovatel'ov boli použité všeobecne známe vzorce (napr. Kotulič, Király, Rajčániová, 2007; Zalai et al., 2007). Pri úprave aktív na čisté operatívne aktíva a pri výpočte ekonomickej pridanej hodnoty bol aplikovaný postup podl'a Maříka a Maříkovej (2005). Tržby boli vyčíslené ako tržby z predaja vlastných výrobkov a služieb, ked’že tržby $\mathrm{z}$ predaja tovaru a tržby z predaja dlhodobého majetku a materiálu vykazovali nulovú hodnotu v prípade všetkých podnikov výberovej vzorky.

\section{Súvislost' medzi finančnými ukazovatel'mi}

Niektoré finančné ukazovatele indikujúce finančnú výkonnost' sa môžu navzájom podporovat', avšak medzi inými nemusí byt' žiadna priama súvislost'. Za účelom identifikácie tejto súvislosti boli finančné ukazovatele výberovej vzorky podnikov podrobené korelačnej analýze. Na základe výsledkov korelačnej analýzy možno identifikovat' ukazovatele, medzi ktorými existuje silná, stredná, mierna, slabá, prípadne žiadna korelácia (súvislost').

Nakol'ko finančný manažment nemožno radit' medzi exaktné vedy, pri formulovaní záverov korelačnej analýzy sa vychádza z „,vol'nejšej“ škály hodnôt korelačných koeficientov. Ak je korelačný koeficient nižší než 0,3 , ide o slabú koreláciu; ak je v rozmedzí od 0,3 do 0,5, ide o miernu koreláciu; ak je v rozmedzí od 0,5 do 0,7, ide o strednú koreláciu a ak je v rozmedzí od 0,7 do 1,0, ide o silnú koreláciu. Korelácia je štatisticky významná vtedy, ak je ukazovatel' významnosti (Sig. z anglického Significance) nižší, než hladina významnosti (1\%-ná alebo 5 \%-ná). Ak napr. korelačný koeficient poradovej korelácie tau b merajúci súvislost' medzi ROE (rentabilita vlastného imania) a EAT/A (rentabilita aktív, kde v čitateli vystupuje čistý zisk) dosahuje hodnotu 0,857 na hladine významnosti $1 \%$, znamená to, že medzi týmito dvoma ukazovatel'mi existuje silná korelácia. Aby ale bola táto korelácia štatisticky významná, ukazovatel' významnosti (Sig.) musí byt' nižší než $1 \%$ (resp. 0,01). V tomto prípade, vychádzajúc z tabul'ky 4 , je ukazovatel' významnosti rovný 0,000 , čo indikuje štatisticky významnú silnú koreláciu medzi ROE a EAT/A. Touto koreláciou sa dá popísat' $99 \%$ prípadov $^{3}$.

\section{Výberová vzorka podnikov}

Príspevok bol spracovaný v rámci riešenia projektu VEGA 1/0541/11 Analýza determinantov výkonnosti subjektov hospodáriacich na pôde podl'a regionálnej diferenciácie, čomu je podriadený aj výber vzorky podnikov.

Za účelom naplnenia hlavného ciel’a predkladaného príspevku bola zostavená výberová vzorka podnikov patriacich do rovnakej divízie podl'a odvetvovej klasifikácie ekonomických činností SK NACE rev. 2. - do divízie 01 sekcie A „Pestovanie plodín a chov zvierat, pol'ovníctvo a služby s tým súvisiace“. Účtovné a doplňujúce údaje o podnikoch vo výberovej vzorke boli získané z informačných listov Ministerstva pôdohospodárstva SR na nosiči CD vo formáte MS ACCESS 2007 (MPSR, 2008). Táto databáza bola získaná z Ministerstva pôdohospodárstva SR za účelom naplnenia projektu VEGA 1/0541/11. Členenie divízie 01 sekcie A je uvedené v nasledovnej tabul'ke.

\footnotetext{
${ }^{3} 100 \%$ - hladina významnosti $1 \%=99 \%$
} 
Tabul'ka 1: Sekcia A, divízia 01 podl'a SK NACE Rev. 2

\begin{tabular}{|c|c|l||}
\hline \hline Divízia & Skupina & SEKCIA A - POLNOHOSPODÁRSTVO, LESNÍCTVO A RYBOLOV \\
\hline \hline $\mathbf{0 1}$ & & Pestovanie plodín a chov zvierat, pol’ovníctvo a služby s tým súvisiace \\
\hline & 01.1 & Pestovanie netrvácnych plodín \\
\hline & 01.2 & Pestovanie trvácnych plodín \\
\hline & 01.3 & Rozmnožovanie rastlín \\
\hline & 01.4 & Chov zvierat \\
\hline & 01.5 & Zmiešané hospodárstvo \\
\hline & 01.6 & Služby poskytované v polnohospodárstve a služby súvisiace so zberom úrody \\
\hline & 01.7 & Lov, odchyt a súvisiace služby \\
\hline
\end{tabular}

Zdroj: spracované podl'a ŠÚ SR (2008a)

Z predmetnej databázy boli vyfiltrované podniky $\mathbf{v}$ právnej forme podnikania družstva, vykazujúce kladný výsledok hospodárenia za bežné účtovné obdobie a nezáporné vlastné imanie. Dôvodom pre kritériá týkajúce sa výsledku hospodárenia a vlastného imania bolo skreslenie niektorých ukazovatel'ov rentability a ukazovatel'ov založených na ekonomickom zisku v prípade ich záporných hodnôt. Po vyfiltrovaní podnikov z informačných listov Ministerstva pôdohospodárstva SR zostalo vo výberovej vzorke 344 podnikov účtujúcich v sústave podvojného účtovníctva. Účtovné údaje o týchto podnikoch boli čerpané za rok 2008.

Len pre porovnanie, podl'a Štrukturálneho zist'ovania fariem 2007 bolo v roku 2007 na území Slovenskej republiky 603 družstiev, ktoré spĺn̆ali aspoň jednu z nasledovných prahových hodnôt (ŠÚ SR, 2008b):

- výmera obhospodarovanej pol'nohospodárskej pôdy je najmenej 0,5 ha alebo

* výmera intenzívnych plodín je najmenej $1500 \mathrm{~m}^{2}$ alebo

- výmera vinohradov je najmenej $500 \mathrm{~m}^{2}$ alebo

- 1 kus hovädzieho dobytka alebo 2 kusy ošípaných alebo 4 kusy oviec alebo 4 kusy kôz alebo

- 50 kusov hydiny alebo

* 100 kusov kožušinových zvierat alebo 100 kusov králikov alebo 5 včelstiev.

\section{Korelačná analýza a výber korelačných koeficientov}

V d'alšom kroku bolo nutné rozhodnút', ktoré korelačné koeficienty budú použité v rámci korelačnej analýzy. V ekonomických vedách je silný predpoklad, že sledované ukazovatele nemajú normálne rozdelenie (t. j. nemajú „,rovnomerne“ rozložené počty hodnôt danej veličiny). Preto nemožno v rámci korelačnej analýzy použit’ akýkol'vek korelačný koeficient.

Ako príklad na veličinu s normálnym rozdelením pravdepodobnosti možno uviest' hod dvoma kockami. Výsledný súčet môže byt' minimálne 2 a maximálne 12. Počet rôznych kombinácií, ktoré môžu vzniknút', je $6^{2}$, t. j. 36 kombinácií. Rozdelením týchto kombinácií do skupín s rovnakým súčtom bodov na kockách sa možno dopracovat' ku pravdepodobnosti dosiahnutia konkrétneho súčtu bodov (tab. 2). Normálne rozdelenie pravdepodobnosti potom zachytáva nasledujúci graf.

Tabul'ka 2: Rozdelenie pravdepodobnosti

\begin{tabular}{|l|l|l|l|l|l|l|l|l|l|l|l|}
\hline Súčet bodov & 2 & 3 & 4 & 5 & 6 & 7 & 8 & 9 & 10 & 11 & 12 \\
\hline Pravdepodobnost' súčtu & $1 / 36$ & $2 / 36$ & $3 / 36$ & $4 / 36$ & $5 / 36$ & $6 / 36$ & $5 / 36$ & $4 / 36$ & $3 / 36$ & $2 / 36$ & $1 / 36$ \\
\hline
\end{tabular}




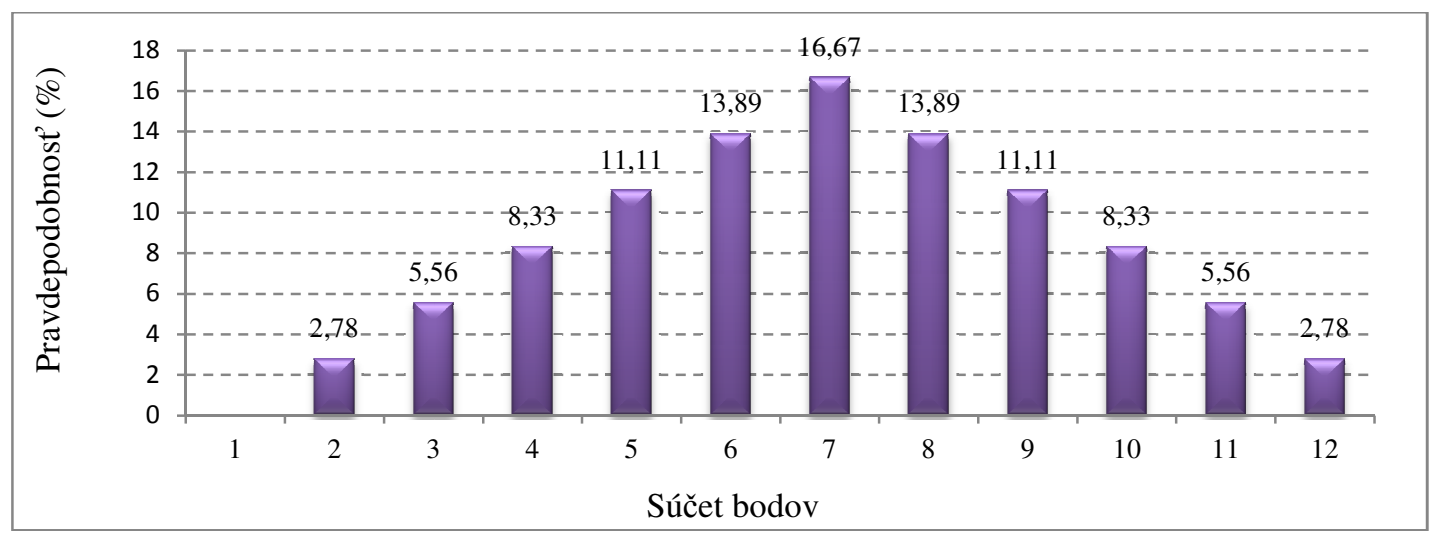

Graf 1: Normálne rozdelenie pravdepodobnosti

Zdroj: Vlastné spracovanie

Aby sa potvrdilo tvrdenie, že finančné ukazovatele nemajú normálne rozdelenie, prostredníctvom štatistického softvéru SPSS for Windows bola preverená normalita jednotlivých premenných (finančných ukazovatel'ov). Použitý bol Kolmogorov-Smirnov test, na základe výsledku ktorého možno tvrdit', že okrem ukazovatel'a obratu aktív (R/A) pri zvyšných 13 ukazovatel'och možno zamietnut' nulovú hypotézu o normálnom rozdelení premennej na hladine významnosti $5 \%$. Vzhl'adom na tento fakt boli vybrané tie korelačné koeficienty, ktoré možno použit' aj pre premenné bez normálneho rozdelenia. Vhodným sa javili nasledovné korelačné koeficienty - Kendallovo tau b a Spearmanovo rho. Bližšie tieto ukazovatele popisuje napr. Hendl (2006).

Pre jednotlivé finančné ukazovatele bola vypočítaná popisná štatistika. Nakol'ko finančné ukazovatele nemajú normálne rozdelenie, popisná štatistika bola doplnená o percentily, ktoré majú v tomto prípade vyššiu vypovedaciu schopnost' než priemerné hodnoty. Kým pri normálnom rozdelení je rozdiel medzi priemerom a 50 \%-ným percentilom (mediánom) zanedbatel'ný, v prípade premenných bez normálneho rozdelenia je tento rozdiel zjavný. Napr. ak medián rentability vlastného imania dosahuje hodnotu 0,0215 (pozri tab. 3), znamená to, že polovica podnikov vo výberovej vzorke dosahuje rentabilitu vlastného imania nižšiu než 0,0215 (resp. 2,15 \%). Priemerná hodnota tohto ukazovatel'a je 5,72\%. Z výsledkov analýzy výberovej vzorky teda možno vyčítat', že priemerná rentabilita vlastného imania podnikov vo výberovej vzorke je $5,72 \%$, pričom polovica podnikov dosahuje rentabilitu vlastného imania nižšiu než $2,15 \%$.

\section{Vedecké metódy použité pri riešení práce a štatistický softvér}

V rámci realizácie výskumu boli popri základných logických metódach použité predovšetkým metódy finančnej analýzy a štatistické metódy. Logické metódy boli použité pri formulácii ústredného problému výskumnej práce, ako aj pri zostavení metodologického postupu jeho naplnenia. Finančná analýza bola použitá pri výpočte jednotlivých finančných ukazovatel'ov. Štatistické metódy boli použité pri výpočte popisnej štatistiky ukazovatel'ov finančnej výkonnosti, pri testovaní ich normálneho rozdelenia a pri realizácii korelačnej analýzy. Logické metódy v súčinnosti s výsledkami štatistického šetrenia vyústili do identifikácie súboru kl’účových indikátorov finančnej výkonnosti podnikov.

Jednotlivé finančné ukazovatele podnikov výberovej vzorky boli vypočítané prostredníctvom tabul'kového procesoru MS EXCEL 2007. Následne takto získané dáta boli prenesené do prostredia štatistického softvéru SPSS for Windows $15.0^{\circledR}$. Test normálneho rozdelenia premenných, popisná štatistika premenných, ako aj korelačná analýza boli vypočítané prostredníctvom softvéru SPSS for Windows $15.0^{\circledR}$. Výstup bol uložený v textovom editore 
MS WORD 2007, kde boli štatistické dáta upravené do formátu tabuliek podporujúcich prezentáciu výsledkov v rámci naplnenia ciel’a príspevku.

\section{Popisná štatistika finančných ukazovatel'ov podnikov vo výberovej vzorke}

Po výpočte vybraných ukazovatel'ov finančnej výkonnosti boli vypočítané vybrané popisné charakteristiky jednotlivých ukazovatel'ov (tabul'ka 3). Okrem ukazovatel'a obratu aktív ${ }^{4}, \mathrm{kde}$ bola nulová hypotéza o normálnom rozdelení ponechaná na d’alšie skúmanie, v prípade zvyšných 13 ukazovatel'ov majú percentily vyššiu vypovedaciu schopnost' než priemery.

Tabul'ka 3: Popisná štatistika ukazovatel'ov finančnej výkonnosti

\begin{tabular}{|c|c|c|c|c|c|c|c|c|c|c|c|c|}
\hline & \multirow{2}{*}{$\begin{array}{l}\text { Počet } \\
\text { pod- } \\
\text { nikov }\end{array}$} & \multirow{2}{*}{ Minimum } & \multirow{2}{*}{ Maximum } & \multirow{2}{*}{ Priemer } & \multirow{2}{*}{$\begin{array}{l}\text { Štandardná } \\
\text { odchýlka }\end{array}$} & \multicolumn{7}{|c|}{ Percentily } \\
\hline & & & & & & 5 & 10 & 25 & 50 & 75 & 90 & 95 \\
\hline EBIT/A & 344 & , 00 & ,53 & ,0447 & ,05596 & ,0058 & ,0088 & ,0143 & ,0258 & ,0519 & 0901 & , 1346 \\
\hline EAT/A & 344 & , 00 & ,42 & ,0305 &, 04802 & ,0005 & ,0011 & ,0035 & ,0130 & ,0375 & ,0716 &, 1011 \\
\hline EBET/A & 344 &,- 01 & ,53 & ,0362 & ,05643 & ,0014 & ,0023 & ,0057 & ,0159 & ,0437 & ,0797 & , 1160 \\
\hline ROE & 344 & , 00 & ,95 & ,0572 & , 10629 & ,0007 & ,0016 & ,0057 & ,0215 & ,0596 & , 1357 & 2330 \\
\hline EBIT/R & 342 & ,01 & 5,57 & , 1765 & ,44053 & ,0173 & ,0228 & ,0385 & ,0753 & , 1569 & ,3279 & ,5408 \\
\hline EAT/R & 342 & ,00 & 4,56 & , 1207 & ,36831 & ,0016 & ,0039 & ,0109 & ,0375 & , 1000 & ,2041 &, 3722 \\
\hline $\mathrm{R} / \mathrm{A}$ & 344 & ,00 & 1,39 & ,4098 & ,23211 & ,0838 &, 1250 & 2390 & ,3908 & ,5609 & ,6774 & ,8016 \\
\hline $\mathrm{PH} / \mathrm{R}$ & 342 & $-11,29$ & 1,25 & ,0217 & 1,11021 &,- 9707 &,- 3194 & ,1196 & , 2590 & ,3719 & ,4513 & ,5299 \\
\hline $\mathrm{PH} / \mathrm{A}$ & 344 & $-1,86$ & ,39 & ,0839 & ,17933 &,- 1159 &,- 0402 & ,0344 & 1011 & , 1772 & ,2461 & ,2855 \\
\hline EVA/NOA & 344 & $-8,02$ & ,03 &,- 3337 & ,46643 &,- 6688 &,- 4657 &,- 3522 &,- 2625 &,- 2011 &,- 1342 &,- 0899 \\
\hline $\begin{array}{l}\text { celková } \\
\text { likvidita }\end{array}$ & 344 & ,08 & 51,14 & 2,7645 & 3,79823 & ,6173 &, 7981 & 1,1601 & 1,7900 & 3,0801 & 5,4059 & 6,8654 \\
\hline $\begin{array}{l}\text { bežná } \\
\text { likvidita }\end{array}$ & 344 & ,02 & 51,14 & 1,4424 & 3,19087 &, 1441 &, 2322 & ,3958 & ,7418 & 1,3627 & 2,6865 & 4,6670 \\
\hline $\begin{array}{l}\text { pohotová } \\
\text { likvidita }\end{array}$ & 344 &,- 02 & 51,05 & ,8184 & 3,06567 & ,0026 & ,0050 & ,0314 & , 1651 &, 5405 & 1,8659 & 3,0008 \\
\hline $\begin{array}{l}\text { platobná } \\
\text { neschopnost' }\end{array}$ & 340 &,- 09 & 278,67 & 4,3869 & 16,52228 & ,3199 &, 5024 & ,9170 & 1,7147 & 3,5738 & 6,4688 & 12,9587 \\
\hline
\end{tabular}

Zdroj: vlastné spracovanie, údaje čerpané z informačných listov MP SR (MP SR, 2008), použitý softvér SPSS for Windows $15.0^{\circledR}$

Vo všeobecnosti možno vyvodit' záver, že po zoradení podnikov podl'a jednotlivých ukazovatel'ov, podnik nachádzajúci sa v polovici radu vykazuje produkčnú silu 2,58\%, rentabilitu aktív (po zdanení) 1,3\%, rentabilitu aktív (pred zdanením) 1,59 \%, rentabilitu vlastného imania $2,15 \%$, rentabilitu tržieb (pred zdanením a platením úrokov) 7,53\%, rentabilitu tržieb (po zdanení) 3,75\%, obrat aktív 0,39, podiel pridanej hodnoty na tržbách $25,9 \%$, podiel pridanej hodnoty na aktívach $10,11 \%$, podiel ekonomickej pridanej hodnoty na čistých operatívnych aktívach -26,25\%, celkovú likviditu 1,79 (optimum je od 1,5 do 2,5), bežnú likviditu 0,74 (optimum je od 1,0 do 1,5), pohotovú likviditu 0,17 (optimum je od 0,2 do 0,8 ) a platobnú neschopnost' 1,71 (ak je ukazovatel' vyšší než 1 , potom záväzky prevyšujú pohl'adávky).

Kým priemerný podnik vykazuje hodnoty ukazovatel'ov rentability (EBIT/A, EAT/A, EBET/A, ROE, EBIT/R, EAT/R), ukazovatel'ov likvidity (platobná neschopnost', celková, bežná a pohotová likvidita) a obratu aktív (R/A) vyššie než podnik nachádzajúci sa v polovici poradia (medián), pri ostatných ukazovatel'och je situácia opačná. Pre ukazovatele pridanej hodnoty (PH/R, PH/A) a pre ukazovatel' podielu ekonomickej pridanej hodnoty na čistých

\footnotetext{
${ }^{4} \mathrm{~V}$ prípade obratu aktív rozdiel medzi priemerom a mediánom (50 \%-ným percentilom) nie je výrazný (pozri tabul'ku 3).
} 
operatívnych aktívach (EVA/NOA) platí, že medián dosahuje vy̌šsiu hodnotu než priemer (graf 2).
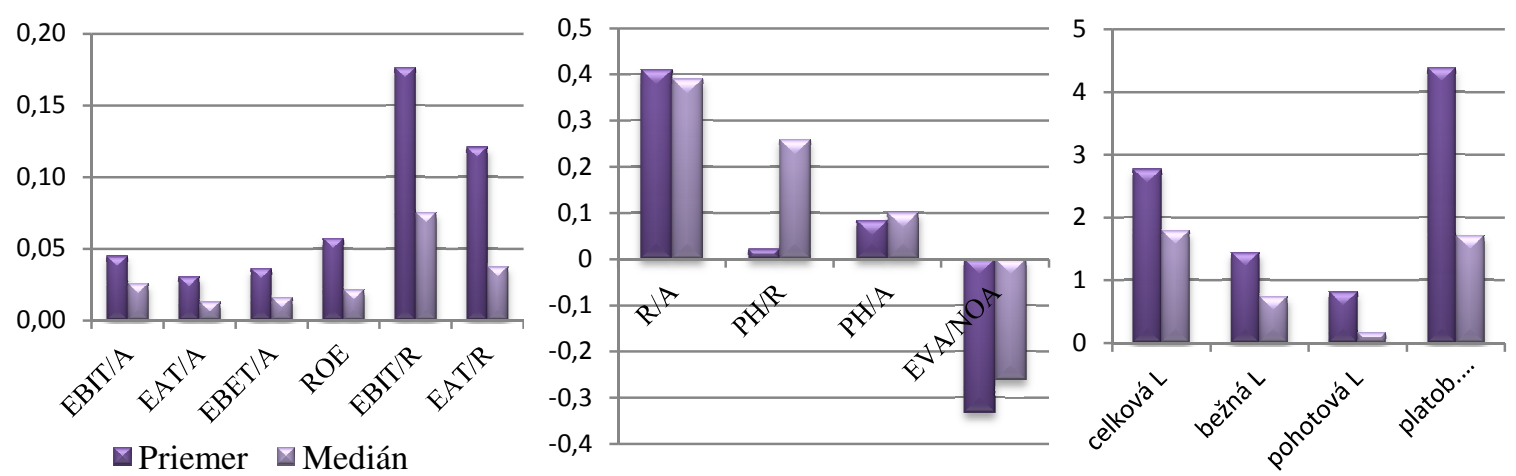

Graf 2: Priemery a mediány finančných ukazovatel'ov

Z pohl'adu teórie riadenia hodnoty možno vnímat' negatívne ukazovatel' podielu ekonomickej pridanej hodnoty na čistých operatívnych aktívach. Dokonca aj posledných $5 \%$ podnikov výberovej vzorky zoradených vzostupne podl'a výkonnosti vykazuje tento ukazovatel' nad hodnotu $-8,99 \%$. Maximálna hodnota tohto ukazovatel'a sú $3 \%$. Taktiež hodnoty rentability vlastného imania možno charakterizovat' ako pomerne nízke. Iba posledných $10 \%$ podnikov vykazuje ROE vyššie než $13,57 \%$.

\section{Korelačná analýza finančných ukazovatel'ov podnikov výberovej vzorky}

Ciel'om realizovaného výskumu bolo prostredníctvom využitia korelačnej analýzy identifikovat' vzt'ahy medzi vybranými finančnými ukazovatel'mi a následne vyselektovat' spomedzi sledovaných ukazovatel'ov tie, ktoré budú tvorit' súbor kl'účových indikátorov finančnej výkonnosti podnikatel'ského subjektu.

V d'alšom kroku boli preto finančné ukazovatele výberovej vzorky podnikov podrobené korelačnej analýze. Tabul'ka 4 zachytáva korelačné koeficienty medzi jednotlivými ukazovatel'mi finančnej výkonnosti. V l’avej spodnej časti sú uvedené Kendallove koeficienty poradovej korelácie tau b. V pravej hornej časti sú uvedené Spearmanove korelačné koeficienty rho. Hodnoty týchto korelačných koeficientov sú rozlíšené šrafovaním podl'a vysvetliviek pod tabul'kou 4. Bodkovaním sú označené koeficienty nad 0,7. Neoznačené zostávajú koeficienty bez potvrdenej významnosti.

Tabul'ka 4: Korelačná matica ukazovatel’ov finančnej výkonnosti

\begin{tabular}{|c|c|c|c|c|c|c|c|c|c|c|c|c|c|c|c|}
\hline \multirow[b]{2}{*}{ tau b/ rho } & & \multirow[b]{2}{*}{ EBIT/A } & \multirow[b]{2}{*}{ EAT/A } & \multirow[b]{2}{*}{ EBET/A } & \multirow[b]{2}{*}{ ROE } & \multirow[b]{2}{*}{ EBIT/R } & \multirow[b]{2}{*}{ EAT/R } & \multirow[b]{2}{*}{$\mathrm{R} / \mathrm{A}$} & \multirow[b]{2}{*}{$\mathrm{PH} / \mathrm{R}$} & \multirow[b]{2}{*}{ PH/A } & \multirow{2}{*}{$\begin{array}{l}\text { EVA/ } \\
\text { NOA }\end{array}$} & \multicolumn{3}{|c|}{ likvidita } & \multirow{2}{*}{$\begin{array}{l}\text { pla- } \\
\text { tobná } \\
\text { nes- } \\
\text { chop- } \\
\text { nost' }\end{array}$} \\
\hline & & & & & & & & & & & & $\begin{array}{l}\text { cel- } \\
\text { ková }\end{array}$ & bežná & $\begin{array}{c}\text { poho- } \\
\text { tová }\end{array}$ & \\
\hline \multirow{3}{*}{ EBIT/A } & koef & 1,000 &, $903 * *$ &, $919 * *$ &, $898 * *$ &, $724 * *$ &, $760 * *$ & $248 * * *$ &,- 052 & , 105 & $125^{*}$ & ,049 & $=131 \%$ & $173 * *$ & 065 \\
\hline & Sig. & . & ,000 & ,000 & ,000 & ,000 &, 000 & .000 & ,334 &, 052 & .021 &, 362 &., 015 & .001 & ,228 \\
\hline & $\mathrm{N}$ & 344 & 344 & 344 & 344 & 342 & 342 & 344 & 342 & 344 & 344 & 344 & 344 & 344 & 340 \\
\hline \multirow{3}{*}{$\mathrm{EAT} / \mathrm{A}$} & koef &, $749^{* *}$ & 1,000 &, $967 * *$ &, $962 * *$ & 668 w &, $888^{* *}$ & $207 * *$ &,- 003 & $124^{*}$ & $231^{* * *}$ & $192^{* *}$ &, $265^{* * *}$ & $319 \cdot 1$ &,- 002 \\
\hline & Sig. & ,000 & & ,000 & ,000 & 000 &, 000 &., 000 & ,956 & .021 &., 000 &, 000 &., 000 & 000 & ,964 \\
\hline & $\mathrm{N}$ & 344 & 344 & 344 & 344 & 342 & 342 & 344 & 342 & 344 & 344 & 344 & 344 & 344 & 340 \\
\hline \multirow{3}{*}{ EBET/A } & koef &, $779 * *$ &, $863^{* *}$ & 1,000 &, $923 * *$ & $685 \mathrm{k}$ &, $854^{* *}$ & $198^{* * *}$ & ,000 & $.122^{*}$ & $.262^{* * *}$ & $.211^{* * *}$ & $.283^{* * *}$ & $(327+\cdots=1$ &,- 020 \\
\hline & Sig. & ,000 & ,000 & 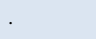 & ,000 & 000 &, 000 & .000 & ,998 & .024 & .000 & .000 & .000 & 000 &, 715 \\
\hline & $\mathrm{N}$ & 344 & 344 & 344 & 344 & 342 & 342 & 344 & 342 & 344 & 344 & 344 & 344 & 344 & 340 \\
\hline \multirow[t]{2}{*}{ ROE } & koef &, $738 * *$ &, $857 * *$ &, $765 * *$ & 1,000 & 609. &, $864^{* *}$ & $198 * *$ &,- 058 & ,068 &, $154^{* * *}$ &, 041 & $146 * *$ & $207 * *$ & ,106 \\
\hline & Sig. & 000 & 000 & ,000 & & 000 & ,000 &, 000 & 288 & 205 &, 004 & ,453 &, 007 & .000 & ,050 \\
\hline
\end{tabular}




\begin{tabular}{|c|c|c|c|c|c|c|c|c|c|c|c|c|c|c|c|}
\hline \multirow{3}{*}{ tau b / rho } & & \multirow[b]{2}{*}{ EBIT/A } & \multirow[b]{2}{*}{ EAT/A } & \multirow[b]{2}{*}{ EBET/A } & \multirow[b]{2}{*}{ ROE } & \multirow[b]{2}{*}{ EBIT/R } & \multirow[b]{2}{*}{$\mathrm{EAT} / \mathrm{R}$} & \multirow[b]{2}{*}{$\mathrm{R} / \mathrm{A}$} & \multirow[b]{2}{*}{$\mathrm{PH} / \mathrm{R}$} & \multirow[b]{2}{*}{$\mathrm{PH} / \mathrm{A}$} & \multirow{2}{*}{$\begin{array}{l}\text { EVA/ } \\
\text { NOA }\end{array}$} & \multicolumn{3}{|c|}{ likvidita } & \multirow{2}{*}{$\begin{array}{l}\text { pla- } \\
\text { tobná } \\
\text { nes- } \\
\text { chop- } \\
\text { nost' }\end{array}$} \\
\hline & & & & & & & & & & & & $\begin{array}{l}\text { cel- } \\
\text { ková }\end{array}$ & bežná & $\begin{array}{l}\text { poho- } \\
\text { tová }\end{array}$ & \\
\hline & $\mathrm{N}$ & 344 & 344 & 344 & 344 & 34 & 342 & 344 & 342 & 344 & 344 & 344 & 344 & 344 & 340 \\
\hline \multirow{3}{*}{ EBIT/R } & koef & $554 \cdots$ & $(494 * 1 *$ & $515 \%$ & $502-1$ & 1,000 &, $860 * *$ & $390 * 0$ & $.263^{* *}$ & $354 * x$ &,- 072 & ,006 &, $134^{*}$ & $205 * *$ & ,095 \\
\hline & Sig. & 000 & 000 & 000 & 000 & . & ,000 & 000 &., 000 & 000 &, 184 & ,916 & .013 &., 000 & ,082 \\
\hline & $\mathrm{N}$ & 342 & 342 & 342 & 342 & 342 & 342 & 342 & 342 & 342 & 342 & 342 & 342 & 342 & 339 \\
\hline \multirow{3}{*}{ EAT/R } & koef & 579 . &, $728 * *$ & 604 & $.694 \times$ &, $705^{* * *}$ & 1,000 & $179 * *$ & $169 * *$ & $170 * *$ & ,092 & $165^{\mathrm{k} *}$ & $.274 \% *$ & $(349 \cdot 1)$ & ,021 \\
\hline & Sig. & 000 &, 000 & 000 & 000 & ,000 & &, 001 &, 002 &, 002 &, 088 &, 002 &, 000 & 0,000 & ,696 \\
\hline & $\mathrm{N}$ & 342 & 342 & 342 & 342 & 342 & 342 & 342 & 342 & 342 & 342 & 342 & 342 & 342 & 339 \\
\hline \multirow{3}{*}{$\mathrm{R} / \mathrm{A}$} & koef & $168^{* * *}$ &, $141^{* * *}$ & $135 * *$ &, $135^{* * *}$ & $266^{* * *}$ & $.120^{* * *}$ & 1,000 & $(377 * 1$ &, $763^{* * *}$ & $35 \cdot 1$ &,- 012 &,- 086 & $-121 *$ &,- 033 \\
\hline & Sig. &., 000 & .000 & .000 & .000 & .000 & .001 & . & 0.000 & ,000 & .000 & 824 &, 112 & .025 &, 543 \\
\hline & $\mathrm{N}$ & 344 & 344 & 344 & 344 & 342 & 342 & 344 & 342 & 344 & 344 & 344 & 344 & 344 & 340 \\
\hline \multirow{3}{*}{$\mathrm{PH} / \mathrm{R}$} & koef &,- 036 & ,000 & ,001 &,- 037 & $-173 * *$ & $-106^{* * *}$ & $264^{* * *}$ & 1,000 &, $822 * *$ & 1631 &, 100 &,- 055 & $-1144^{*}$ & $163^{* * *}$ \\
\hline & Sig. & ,326 & ,994 & ,985 & ,309 &, 000 &, 003 &, 000 & & ,000 & 000 &, 065 & ,309 & .035 &, 003 \\
\hline & $\mathrm{N}$ & 342 & 342 & 342 & 342 & 342 & 342 & 342 & 342 & 342 & 342 & 342 & 342 & 342 & 339 \\
\hline \multirow{3}{*}{$\mathrm{PH} / \mathrm{A}$} & koef & $.078 *$ & $.093^{\text {*** }}$ & $.089 *$ & ,055 & $-.240^{\mathrm{k} *}$ & $-103^{* * *}$ & $382-\cdots$ & $660 \times$ & 1,000 & 620.15 & $109^{*}$ &,- 038 & $-.112^{*}$ & $156 * *$ \\
\hline & Sig. & $=030$ & $=010$ & 013 &, 131 & 000 &, 004 & 000 & 000 & . & .000 & 043 & ,483 & 037 & 004 \\
\hline & $\mathrm{N}$ & 344 & 344 & 344 & 344 & 342 & 342 & 344 & 342 & 344 & 34 & 344 & 344 & 344 & 340 \\
\hline \multirow{3}{*}{ EVA/NOA } & koef & $089 \%$ & $164^{* * *}$ & $191^{* * *}$ & $1112^{* * *}$ &,- 043 & $.073^{*}$ & $218 \% *$ & $457 * *$ & $453 * *$ & 1,000 & $376=1$ & $287^{* * *}$ & $146^{* * *}$ & $339 \cdot=$ \\
\hline & Sig. &, 014 & .000 & .000 & .002 &, 233 & 045 & .000 & 000 & 000 & & 000 & .000 & .007 & 000 \\
\hline & $\mathrm{N}$ & 344 & 344 & 344 & 344 & 342 & 342 & 344 & 342 & 344 & 344 & 344 & 344 & 344 & 340 \\
\hline \multirow{3}{*}{$\begin{array}{l}\text { celková } \\
\text { likvidita }\end{array}$} & koef &, 030 & $127^{* * *}$ & $141 * *$ &, 027 &,- 001 & $110 * *$ &,- 007 & $.075 *$ & $0,077 *$ & $272 * *$ & 1,000 &, $845 * *$ &, $714^{* * *}$ & $342+x$ \\
\hline & Sig. &, 411 &, 000 &., 000 &, 460 &, 973 &, 002 &, 838 &., 039 &, 033 &, 000 & . & ,000 & ,000 & 000 \\
\hline & $\mathrm{N}$ & 344 & 344 & 344 & 344 & 342 & 342 & 344 & 342 & 344 & 344 & 344 & 344 & 344 & 340 \\
\hline \multirow{3}{*}{$\begin{array}{l}\text { bežná } \\
\text { likvidita }\end{array}$} & koef & $091^{*}$ & $181^{* * *}$ & $196^{* * *}$ & $101^{* * *}$ & $089^{*}$ & $185^{* * *}$ &,- 060 &,- 036 &,- 026 & $202^{* * k}$ & .6592 & 1,000 &, $819^{* *}$ & 469 \\
\hline & Sig. & $\overline{z, 012}$ & 2,000 & 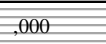 &, 005 & $\overline{\bar{z}, 015}$ & 2,000 & ,099 &, 317 & ,467 & $\overline{2,000}$ & 000 & . & ,000 & 000 \\
\hline & $\mathrm{N}$ & 344 & 344 & 344 & 344 & 342 & 342 & 344 & 342 & 344 & 344 & 344 & 344 & 344 & 340 \\
\hline \multirow{3}{*}{$\begin{array}{l}\text { pohotová } \\
\text { likvidita }\end{array}$} & koef &, $118 * *$ &, $215^{* * *}$ & $2,220 * *$ & $2141^{* * *}$ & ,134** &, $234 * \%$ &,$- 080^{*}$ & $-072^{*}$ & $-.072 *$ & $104^{* * *}$ & $53 \times$ & 635 & 1,000 & $158 * *$ \\
\hline & Sig. & .001 & .000 & .000 & .000 & .000 & .000 & .026 & .046 & .045 & .004 & 000 & 000 & . & .003 \\
\hline & $\mathrm{N}$ & 344 & 344 & 344 & 344 & 342 & 342 & 344 & 342 & 344 & 344 & 344 & 344 & 344 & 340 \\
\hline \multirow{3}{*}{$\begin{array}{l}\text { platobná } \\
\text { neschop- } \\
\text { nost' }\end{array}$} & koef & ,044 &,- 005 &,- 014 &, 070 & ,064 & ,013 &,- 025 & $.116^{* * *}$ & $109^{* * * *}$ & $238^{* k * k}$ & .241 k* & $348 * 1$ & $112^{* * *}$ & 1,000 \\
\hline & Sig. &, 226 & ,900 & ,698 &, 053 & ,079 &, 719 & ,500 &, 001 & 003 & 000 & 000 & 000 &, 002 & \\
\hline & $\mathrm{N}$ & 340 & 340 & 340 & 340 & 339 & 339 & 340 & 339 & 340 & 340 & 340 & 340 & 340 & 340 \\
\hline
\end{tabular}

Poznámka: V l’avej spodnej časti sú uvedené Kendallove koeficienty poradovej korelácie tau b. V pravej hornej časti sú uvedené Spearmanove korelačné koeficienty rho.

\begin{tabular}{|c|c|c|c|}
\hline \multicolumn{2}{|l|}{ Vysvetlivky: } & $* *$ & Korelácia na hladine významnosti 0.01 (obojstranná) \\
\hline & nepotvrdená korelácia & $*$ & Korelácia na hladine významnosti 0.05 (obojstranná) \\
\hline do 0,3 & slabá závislost' & tau b & Kendallov koeficient poradovej korelácie \\
\hline od 0,3 do 0.5 & mierna závislost' & rho & Spearmanov korelačný koeficient \\
\hline $0 \mathrm{~d} 0.5 \mathrm{~d} 00 \mathrm{2}$ & stredná závislost' & Sig. & hladina významnosti (z anglického significance) \\
\hline od 0,7 do 1 & silná závislost' & $\mathrm{N}$ & počet podnikov vo výberovej vzorke \\
\hline
\end{tabular}

Zdroj: vlastné spracovanie, údaje čerpané z informačných listov MP SR (MP SR, 2008), použitý softvér SPSS for Windows $15.0^{\circledR}$ 


\section{Zhrnutie výsledkov korelačnej analýzy}

$\mathrm{Na}$ základe vypočítaných korelačných koeficientov medzi jednotlivými ukazovatel'mi finančnej výkonnosti boli vyselektované ukazovatele, ktoré možno považovat' za kl'účové pri meraní a sledovaní vývoja finančnej výkonnosti podniku. Nasledovný text postupne popisuje výber týchto kl’účových indikátorov.

\section{Selekcia ukazovatel'ov rentability}

Produkčná sila podniku (EBIT/A) sa považuje z pohl'adu finančnej teórie za jeden z vrcholových ukazovatel'ov, nakol'ko nezohl'adňuje finančnú štruktúru podniku. Tento ukazovatel' je v silnej pozitívnej korelácii ${ }^{5}$ s nasledovnými ukazovatel'mi: EAT/A, EBET/A, ROE, EBIT/R a EAT/R.

Nakol'ko vlastník podniku sleduje zhodnotenie ním vloženého kapitálu do podnikania, je vhodné ponechat' $\mathrm{v}$ súbore indikátorov finančnej výkonnosti podniku spomedzi vyššie uvedených ukazovatel' ROE. Ukazovatel' ROE vykazuje silnú pozitívnu koreláciu s EAT/A a EBET/A (ktoré sú zároveň v silnej korelácii s produkčnou silou). Preto sa javí ako účelné tieto dva ukazovatele (EAT/A a EBET/A) vylúčit’ zo súboru indikátorov.

Spomedzi ukazovatel'ov rentability tržieb (EBIT/R a EAT/R) je ukazovatel' EAT/R v silnejšom vzt'ahu s ROE než EBIT/R. Preto by mal byt' ukazovatel' EBIT/R súčast'ou súboru výkonnostných indikátorov.

Zo šiestich ukazovatel'ov rentability zostávajú v súbore tri - EBIT/A, EBIT/R a ROE. Kým prvé dva ukazovatele nezohl'adňujú štruktúru pasív podniku, ukazovatel' ROE priamo závisí od výšky vlastného imania podniku.

\section{Selekcia ukazovatel'ov aktivity, pridanej hodnoty a moderných ukazovatel'ov}

Spomedzi štyroch ukazovatel'ov (R/A, PH/R, PH/A a EVA/NOA) boli vybrané tri ukazovatele. Ukazovatel' PH/A je v silnej korelácii s PH/R. Zároveň korelácia medzi PH/A a R/A je 0,763** (Spearmanovo rho), kým korelácia medzi PH/R a R/A je 0,377** (Spearmanovo rho). Preto je vhodnejšie upustit' od sledovania PH/A a sledovat' prednostne PH/R a R/A. Ku vyššie zvýrazneným indikátorom sa pridávajú d'alšie dva - PH/R a R/A.

Ukazovatel' EVA/NOA nie je v silnej korelácii s ostatnými ukazovatel'mi, aj ked' najsilnejší vzt'ah je s PH/R $(0,631 * *)$ a PH/A $(0,620 * *)$ (Spearmanovo rho). Preto by mal byt' ukazovatel' EVA/NOA taktiež súčast'ou súboru indikátorov finančnej výkonnosti.

\section{Selekcia ukazovatel'ov likvidity}

Ukazovatele likvidity (okrem platobnej neschopnosti) sú vo vzájomne silnom vzt’ahu (viac než $\left.0,714^{* *}\right)$. Preto spomedzi nich možno vybrat' celkovú likviditu, ktorá nevykazuje štatisticky významnú závislost' s produkčnou silou podniku (EBIT/A). Posledným ukazovatel'om v súbore výkonnostných indikátorov by mal byt' ukazovatel' platobnej neschopnosti, ktorý je s viacerými ukazovatel'mi v nevýznamnom vzt'ahu, prípadne v slabom alebo miernom vzt'ahu.

\footnotetext{
${ }^{5}$ Výnimkou je stredná korelácia medzi EBIT/A a EBIT/R a medzi EBIT/A a EAT/R meraná korelačným koeficientom tau $b$.
} 


\section{Kl’účové indikátory finančnej výkonnosti podniku}

Spomedzi 14 analyzovaných finančných ukazovatel'ov bolo do súboru kl'účových finančných indikátorov zvolených osem:

- EBIT/A - produkčná sila podniku daná pomerom hrubého zisku pred platením úrokov ku celkovým aktívam podniku,

- EBIT/R - rentabilita tržieb daná pomerom hrubého zisku pred platením úrokov ku tržbám,

- ROE - rentabilita vlastného imania daná podielom čistého zisku na vlastnom imaní podniku,

- $\mathbf{P H} / \mathbf{R}$ - podiel pridanej hodnoty na celkových tržbách podniku,

- R/A - obrat aktív daný podielom tržieb na celkových aktívach podniku,

* EVA/NOA - podiel ekonomickej pridanej hodnoty na čistých operatívnych aktívach podniku,

* celková likvidita daná pomerom obežného majetku ku krátkodobým záväzkom podniku a

• platobná neschopnost' daná pomerom záväzkov a pohl'adávok.

\section{Záver}

Otvorením sa slovenskej ekonomiky zahraničným trhom prinieslo podnikatel'ským subjektom nielen nové výzvy, ale aj viaceré hrozby. V súvislosti so zostrujúcou sa konkurenciou, ktorú otvorenost' trhov prináša, na to, aby podnik zotrval na trhu čo najdlhšie a prekonal prípadné krízy, je potrebné, aby posilňoval svoju výkonnost'. Ako uvádzajú viacerí autori, napr. Kislingerová (2007) či Neumaierová a Neumaier (2002), rast finančnej výkonnosti podniku podporuje rast hodnoty podniku ako celku, ale i vo vzt’ahu k jeho vlastníkom. A tí v súvislosti s negatívnymi tlakmi globalizačných procesov postupne presúvajú dôraz na moderné ukazovatele finančnej výkonnosti, ktoré sú založené na teórii riadenia hodnoty podniku a teda odhadujú tvorbu hodnoty pre vlastníka ako investora vol’ných finančných prostriedkov. Moderné ukazovatele vychádzajúce z ekonomického zisku podniku tak dopín̆ajú tradičné absolútne a pomerové finančné ukazovatele.

V rámci finančnej analýzy a predikcie finančného zdravia podniku zvyknú finanční analytici sledovat' pomerne vel'ké množstvo týchto ukazovatel'ov. A práve vel'ký okruh sledovaných ukazovatel'ov môže vyústit' do zbytočného úsilia riadit' niečo, čo potrebné riadit' v skutočnosti nie je nutné. Manažéri (a častokrát aj samotní analytici) l'ahko strácajú v spleti čísel zmysel svojho úsilia. Navyše, mnohé ukazovatele sú vo vzájomne silnom vzt'ahu - navzájom sa podporujú. Preto je účelné vyselektovat' spomedzi ukazovatel'ov finančnej výkonnosti tie, medzi ktorými je nezávislý vzt’ah, prípadne štatisticky nevýznamný vzt’ah. Takýmto spôsobom je možné zredukovat' počet ukazovatel'ov tvoriacich sledovaný súbor indikátorov finančnej výkonnosti.

Za účelom naplnenia ciel’a príspevku bola zostavená a analyzovaná výberová vzorka 344 podnikov v právnej forme družstva patriacich podl'a odvetvovej klasifikácie ekonomických činností SK NACE rev. 2. do divízie „Pestovanie plodín a chov zvierat, pol’ovníctvo a služby s tým súvisiace“. Podniky výberovej vzorky vykazovali zisk za bežné účtovné obdobie (rok 2008) a kladné vlastné imanie.

$\mathrm{Na}$ základe výsledkov korelačnej analýzy ukazovatel'ov finančnej výkonnosti boli vyselektované ukazovatele, ktoré možno odporučit' finančným manažérom ako kl'účové pri riadení finančnej výkonnosti podniku. Z pôvodných 14 analyzovaných ukazovatel'ov bolo vybraných 8 . V súbore kl’účových indikátorov finančnej výkonnosti zostávajú 4 ukazovatele 
rentability (EBIT/A, EBIT/R, ROE a PH/R), 2 ukazovatele likvidity (celková likvidita a platobná neschopnost'), 1 ukazovatel' aktivity (R/A) a 1 moderný ukazovatel' (EVA/NOA).

Aj ked' výberová vzorka podnikov patrí do primárneho sektora ekonomiky, obdobné vzt'ahy medzi finančnými ukazovatel'mi možno očakávat' aj v prípade iných podnikov. Preto sledovanie vývoja a riadenie týchto kl'účových indikátorov finančnej výkonnosti môže byt' prínosom aj pre podniky z iných odvetví národného hospodárstva. Navyše, podniky v právnej forme družstva, s kladným výsledkom hospodárenia, s kladným vlastným imaním a pôsobiace v divízii „Pestovanie plodín a chov zvierat, pol'ovníctvo a služby s tým súvisiace“ môžu hodnoty jednotlivých finančných ukazovatel'ov porovnat' s popisnou štatistikou podnikov výberovej vzorky.

Záverom treba ešte zdôraznit', že finančné ukazovatele poskytujú v prvom rade náhl'ad do minulosti a nepodávajú dostatočné informácie o možnom vývoji či perspektíve podniku. Preto by mal byt' súbor klúčových indikátorov doplnený aj o nefinančné ukazovatele, ktoré vytvárajú dynamický obraz o konkurenčnom postavení podniku na trhu a napomáhajú tak prepojit' krátkodobú výkonnost' s dlhodobou strategickou víziou podniku. Navyše, podl'a finančnej teórie (napr. Kaplan, Norton, 2008) existuje priama súvislost' medzi výkonnost'ou meranou vo finančnej a nefinančnej perspektíve. Posilnenie finančnej výkonnosti preto v značnej miere podporuje výkonnost' podniku meranú nefinančnými ukazovatel'mi, a naopak.

\section{Literatúra:}

[1] HENDL, J. 2006. Přehled statistických metod zpracování dat : Analýza a metaanalýza dat. Praha: Portál, s.r.o., 2006, 583 s. ISBN 80-7367-123-9.

[2] MP SR. 2008. Informačné listy Ministerstva pôdohospodárstva Slovenskej republiky, 2008 [CD nosič $]$

[3] KAPLAN, S. R., NORTON, D. P. 2008. Balanced Scorecard : Strategický systém měrení výkonnosti podniku. Praha: Management Press, 2008, 268 s. ISBN 978-80-7261-177-5.

[4] KISLINGEROVÁ, E., NOVÝ, I. et al. 2005. Chování podniku v globalizujícím se prostředí. Praha: C. H. Beck, 2005, 422 s. ISBN 80-7179-847-9.

[5] KISLINGEROVÁ, E. 2007. Výkonnost podniku v nové ekonomice. In: Finance a výkonnost firem ve vědě, výuce a praxi. Zlín: Universita Tomáše Bati ve Zlíně, 2007. ISBN 978-80-7318-536-7.

[6] KOTUliČ, R., KIRÁLY, P., RAJČÁNIOVÁ, M. 2007. Finančná analýza podniku. Bratislava: IURA edition, 2007, 206 s. ISBN 978-80-8078-117-0.

[7] MAŘÍK, M., MAŘÍKOVÁ, P. 2005. Moderní metody hodnocení výkonnosti podniku. Praha: Ekopress, s.r.o., 2005, 164 s. ISBN 80-86119-61-0.

[8] NEUMAIEROVÁ, I., NEUMAIER, I. 2002. Výkonnost a tržní hodnota firmy. Praha: Grada, 2002, 215 s. ISBN 80-247-0125-1.

[9] ŠÚ SR, 2008a. Štatistická klasifikácia ekonomických činností, Rev. 2 (2008). [cit. 5.3.2010]. Dostupné na internete: <http://portal.statistics.sk/files/Sekcie/sek_200/ Klasifikacie/NACE_syst.rtf >

[10] ŠÚ SR, 2008b. Vybrané ukazovatele - metodické vysvetlivky. Štrukturálne zist'ovanie fariem. [cit. 5.3.2010] <http://portal.statistics.sk/showdoc.do?docid=7387>

[11] ZALAI, K. et al. 2007. Finančno-ekonomická analýza podniku. 5. vyd., Bratislava: Sprint vfra, 2007, 355 s. ISBN 978-80-89085-74-1.

[12] ZÁVARSKÁ, Z. 2008. Finančné verzus nefinančné indikátory výkonnosti podniku. In: Evropské finanční systémy 2008 - sborník přispěvkú z mezinárodní vědecké konference. 
Brno: Masarykova univerzita, Ekonomicko-správní fakulta, 2008. ISBN 978-80-2104628-3.

Klasifikace JEL: G32, M21

Ing. Zuzana Závarská, PhD.

Katedra ekonómie a ekonomiky - odborný asistent

Fakulta manažmentu

Prešovská univerzita v Prešove

Slovenská č. 67, 08001 Prešov

Slovenská republika

zavarska@unipo.sk 
